\title{
Zero Tillage Technology in Jute Cultivation: A Successful Venture in West Bengal
}

\author{
Biplab Mitra $^{1}$ *, Prateek Madhab Bhattacharya ${ }^{1}$, Abhas Kumar Sinha ${ }^{1}$, \\ Rajat Chatterjee ${ }^{2}$ and Apurba Kumar Chowdhury ${ }^{1}$
}

${ }^{1}$ Uttar Banga Krishi Viswavidyalaya, Pundibari, Coochbehar, West Bengal-736165, India

${ }^{2}$ Department of Agriculture, Government of West Bengal, India

*Corresponding author

\section{A B S T R A C T}

\begin{tabular}{|c|}
\hline Keywords \\
\hline $\begin{array}{l}\text { Jute, Productivity, } \\
\text { Profitability, } \\
\text { Technology index, } \\
\text { Zero tillage }\end{array}$ \\
\hline Article Info \\
\hline $\begin{array}{l}\text { Accepted: } \\
15 \text { April } 2020 \\
\text { Available Online: } \\
10 \text { May } 2020\end{array}$ \\
\hline
\end{tabular}

Farmers' participatory demonstrations on jute cultivation using zero tillage (ZT) technology were conducted in West Bengal through standardized conservation agriculture (CA)-jute protocols developed jointly by Uttar Banga Krishi Viswavidyalaya and International Maize and Wheat Improvement Centre (CIMMYT). The results of demonstration indicated a significant yield increase under ZT over conventional practices.On an average, an yield increase of 25.83-27.83\% under zero tillage technology reflected the positive effect of demonstration over the existing practices. It was attributed to maintenance of higher plant population with increased plant height and basal diameter under ZT. There was a considerable saving in total man-days requirement (41-42 mandays over one hectare) for the crop due to herbicidal management of weeds. The higher returns with reduced cost of cultivation under $\mathrm{ZT}$ technology helped to register a higher profit in terms of $\mathrm{B}: \mathrm{C}$ ratio (3.36 -4.19) over $\mathrm{CT}$ practices (1.99 - 2.59). The successive decreased value of technology index $(20.52-17.10 \%)$ reflected the feasibility of the technology. It can be concluded that ZT technology can be considered as a successful technology in jute in terms of productivity as well as profitability for further adoption of technology.

\section{Introduction}

Jute (Chorchorus spp) plays an important role in our country's economy, particularly in eastern and north eastern states. Jute and allied fibre farming, trading and industry provide sustenance to more than five million people of our country (Mahapatra et al., 2009). West Bengal is the major jute growing state sharing about three- fourth of the total production of the country. It is the second most important commercial fibrecrop next to cotton grown mostly in humid tropical or subtropical climate under rainfed condition. It is predominantly cultivated by marginal and small farmers of Indo-Bangladesh subcontinent.

Jute-rice is a popular cropping system in northern part of West Bengal. Jute was 
initially regarded as "Golden Fibre" considering its national importance. However, the area under this crop in West Bengal is gradually declining due to various reasons and at present around 5.15 lakh ha was under cultivation with an annual production of 75.11 lakh MT (Anonymous, 2018). Though the warm humid climate with occasional rainfall during pre-monsoon season in the region is very suitable for the crop, but with ever increasing area under rabi maize throughout the terai region of West Bengal, area under jute gets lowered down each year. The negative growth in jute area in the country as a whole was reflected by Kumari et al., (2018). Again, under the scenario of labour migration and less preference of agricultural work due to greater drudgery and risk involvement, the farmers are not interested to grow jute in which a lot of man-days required for weeding in a broadcasted crop as well post-harvest operation like steeping, retting and fibre extraction. Further the marketing of the fibre is substantially controlled by middleman which deprive the farmers in getting remunerative price. However, in recent years, the crop is gaining importance under the context of environment pollution and the preference of the people to use natural products instead of man-made synthetic substitutes which are non-biodegradable.

Due to low levels of mechanization, high labour requirements and costs, the overall production costs are high which results in low farm profits in various cropping systems (Gathala et al., 2016; Brown et al., 2017). It has promoted a practice which is ecologically sustainable as well as profitable. The conservation agriculture (CA) based new agronomic management practices, comprising three basic steps: minimum or no tillage, residue retention \& management and judicious crop rotations, are advocating to overcome above challenges and it is serving as a viable technology through which yield can be increased sustainably with reduced cost of cultivation (Hobbs et al., 2008 ; Krishna et al., 2016). In Gangetic plains, most of the conservation agriculture research work was conducted on cereal crops, wheat in particular where it was demonstrated that CAbased management can enhance yields with reduced cost of cultivation (Chauhan et al., 2012; Gathala et al., 2013; Mitra et al., 2019). Through conduction of a number of participatory trials in eastern Gangetic plains, Islam et al., (2019) reported increased yields with improved water productivity under various rice-based systems, even in system involving jute. It was a huge challenge to sow such a small seeded crop through zero till drill, but intense effort of CIMMYT in collaboration with Uttar Banga Krishi Viswavidyalaya standardised the protocols for CA-jute under an Australian Centre for International Agriculture Research (ACIAR) funded project entitled "Sustainable and Resilient Farming System Intensification in Eastern Gangetic Plains (SRFSI)"and this protocol was tested in various farmers fields. It was probably the first attempt in India to sow jute with multi-crop planter. Attempts were also taken to sow it with happy seeder under wheat residue which was also successful. The productivity as well the production economics were thoroughly calculated to judge the feasibility of CA-jute in farmers' field.

\section{Materials and Methods}

Farmers' participatory demonstrations were conducted in Hawargari, Ghughumari, Barashakdal, Barsimulguri, Patakamari and Latapota villages of Coochbehar and Kalaberia Banabasti, Dakshin Kamsing and Purba Kathalbari villages of Alipurduar district of West Bengal during pre-kharif season of 2018 and 2019 (Table 1) through standardized CA-jute protocols developed by UBKV and CIMMYT. The seeding, fertilizer 
management and weed management of the crop were standardized through conduction of station trials. The protocol of CA-jute was described in Table- 2 .

The package of practices adopted in conventionally tilled (CT)-jute plots were quite different crop CA-jute. The seeds were mostly broadcasted @ $7.5 \mathrm{~kg} / \mathrm{ha}$ with or without seed treatment. Fertilizer dose was kept at 60-30-30 following state government's recommendation. Weeding was totally performed manually.

Before demonstration, group meetings were conducted in each and every village where problems associated with jute cultivation were discussed and the advantages of growing jute under CA was described. A probable list of interested farmers was prepared from the meeting through intervention of the officers of Department of Agriculture, Government of West Bengal, being a partner in SRFSI project. Further, team of scientists from UBKV and government grass root level extension officials visited the land of the selected farmer in presence of the villagers. Before implementing the programme, the skill development trainings were organized involving the selected farmers.

Field days and other extension programmes were also organized inviting the farmers of the demonstrated and nearby villages. Mitra and Samajdar (2013) described the role of frontline demonstration as an effective tool for enhancing the yield of jute fibre in subHimalayan plains of West Bengal, India.

Data on major yield attributing character and fibre yield were collected from both demonstration and control plots. Technology gap, extension gap and technology index were worked out using the formula used by Mitra et al., (2014).
The formula was cited below:

Technology gap $(\mathrm{kg} / \mathrm{ha})=$ Potential yield (kg/ha) -Demonstration yield ( $\mathrm{kg} / \mathrm{ha})$

Extension gap $(\mathrm{kg} / \mathrm{ha})=$ Demonstration yield (kg/ha) - Farmers' yield (kg/ha)

Technology Index $(\%)=($ Potential yield Demonstration yield) $/$ Potential yield $\times 100$

\section{Results and Discussion}

The results of demonstration indicated a significant yield increase under ZT over CT technology (Table 3). In both the years, the fibre yield obtained under ZT was higher (3020 and $3150 \mathrm{~kg}$ /ha during 2018 and 2019, respectively) with the corresponding values of 2400 and $2470 \mathrm{~kg} / \mathrm{ha}$ under CT. It was also noted that the demonstration yield was higher in 2019 (3150 kg/ha) over 2018 (3020 kg/ha). It was attributed to maintenance of higher plant population with increased plant height and basal diameter (Table 4) in 2019.The plant height recorded under $\mathrm{ZT}$ jute was varying between $310-350 \mathrm{~cm}$ with basal diameter ranging between $20-25 \mathrm{~mm}$, much higher than CT-jute over both the years of demonstration. Moreover, the plant population maintained in the field in the second year was quite close to 5 lakh/ha, the optimum plant population for the crop. With greater precision in calibrating the seeding machines over the years, it was possible to maintain optimum plant population in the field for which the crop performed better due to increased utilization of resources. Maintaining proper seed rate vis-a-vis optimum plant population was supposed to be the most crucial factor in determining the growth of jute plant and for obtaining maximum yield (Islam and Ali, 2017). On an average, the yield increase of 25.83-27.83\% in ZT-jute reflected the positive effect of demonstration over the existing practices. The variation in yield attributing characters as 
well as yields in the successive years could also be attributed to variation in the prevailing climatic condition during the crop growth period. Successive increase in demonstration yield over the years reflects the success of the demonstration (Mitra et al., 2014).

In ZT technology the weeds were controlled through herbicides which curtailed the mandays requirement vis-à-vis cost incurred towards weeding to a great extent. Manual weeding alone contributed a high proportion of total cost of cultivation. In this region, high pre-monsoon showers coupled with high humidity results in huge weed infestation and farmers have to bear major share of expenditure for controlling weeds (Bhattacharya et al., 2004; Ghorai et al., 2004). Use of post-emergence herbicides may curtail the cost of cultivation and this practice in jute was supposed to be an economic option (Datta et al., 2015; Mitra et al., 2017). Due to herbicidal control of weeds, there was a considerable saving in total man-days requirement for the crop as a whole and it was revealed that under zero tillage there was saving of 41-42 man-days over one hectare (Table 5).

As far as production economics were concerned, the data clearly indicated the advantages of ZT technology over the conventional practices (Table 6). The higher gross and net returns with reduced cost of cultivation under ZT technology helped to register a higher profit. The $\mathrm{B}: \mathrm{C}$ ratio under ZT technology was much higher(3.36 and 4.19 in 2018 and 2019, respectively) over CT practices (1.99 and 2.59 during 2018 and 2019, respectively). The higher profit in 2019 over 2018 was due to higher market price of jute fibre prevailed during 2019.

Table.1 Details of demonstration

\begin{tabular}{|c|c|c|c|c|}
\hline Year & No. of Demo. & $\begin{array}{c}\text { No. of farmers } \\
\text { involved }\end{array}$ & $\begin{array}{c}\text { Area } \\
\text { (ha) }\end{array}$ & Variety used \\
\hline $\mathbf{2 0 1 8}$ & 46 & 135 & 18.25 & JBO 2003H \\
\hline $\mathbf{2 0 1 9}$ & 85 & 240 & 28.80 & JBO 2003H \\
\hline Total & $\mathbf{1 3 1}$ & $\mathbf{3 7 5}$ & $\mathbf{4 7 . 0 5}$ & - \\
\hline
\end{tabular}

Table. 2 CA-jute protocols developed by UBKV and CIMMYT

\begin{tabular}{|c|c|}
\hline Days of activities & Details of activities \\
\hline 6 days before seeding & Spraying of Glyphosate @ 1 kg a.i./ha \\
\hline On the day of seeding & $\begin{array}{l}\text { Sowing with zero-till-drill (seed rate @ } 7.5 \mathrm{~kg} / \mathrm{ha} \text { ) after mixing with dry } \\
\text { vermicompost }(60 \mathrm{~kg} / \mathrm{ha})\end{array}$ \\
\hline On the day of seeding & $\begin{array}{l}\text { Fertilizer application through multi-crop planter @ N-P-K }(10-26-26) @ 150 \\
\mathrm{~kg} / \mathrm{ha} \text {; seeds to be treated with Carbendazim @ 2-3 g/kg of seeds/Trichoderma } \\
\text { @ } 5 \mathrm{~g} / \mathrm{kg} \text { of seeds }\end{array}$ \\
\hline 1-2 days after seeding & Spraying of pretilachlor @ $0.5 \mathrm{~kg}$ a.i./ha \\
\hline 15-20 days after seeding & Irrigation + first top dressing (urea @ 90 kg/ha) \\
\hline 20-25 days after seeding & Spraying of propaquizalofop @ $50 \mathrm{~g}$ a.i./ha + ethoxysulfuron @ $18 \mathrm{~g}$ a.i./ha \\
\hline 30-35 days after seeding & Irrigation + second top dressing (urea@60kg/ha + MOP @30 kg/ha) \\
\hline 40-45 days after seeding & Spraying of carbendazim @0.1\% \\
\hline
\end{tabular}


Table.3 Yield performances under demonstration

\begin{tabular}{|c|c|c|c|c|}
\hline Year & $\begin{array}{c}\text { Potential yield } \\
\text { (kg/ha) }\end{array}$ & $\begin{array}{c}\text { Demo.(ZT) yield } \\
\text { (kg/ha) }\end{array}$ & $\begin{array}{c}\text { Local check(CT) } \\
\text { yield(kg/ha) }\end{array}$ & $\begin{array}{c}\text { \% yield } \\
\text { increase }\end{array}$ \\
\hline $\mathbf{2 0 1 8}$ & 3800 & $3020^{\mathrm{a}}$ & $2400^{\mathrm{b}}$ & 25.83 \\
\hline $\mathbf{2 0 1 9}$ & 3800 & $3150^{\mathrm{a}}$ & $2470^{\mathrm{b}}$ & 27.53 \\
\hline
\end{tabular}

Within a row means followed by different letter are significantly different $(\mathrm{p}=0.05)$ using $\mathrm{T}$ test

Table.4 Comparison between CT-Jute and ZT-Jute in relation to major yield attributing characters

\begin{tabular}{|c|c|c|c|c|}
\hline \multirow{2}{*}{ Yield parameters } & \multicolumn{2}{|c|}{ ZT-Jute } & \multicolumn{2}{c|}{ CT-Jute } \\
\cline { 2 - 5 } & $\mathbf{2 0 1 8}$ & $\mathbf{2 0 1 9}$ & $\mathbf{2 0 1 8}$ & $\mathbf{2 0 1 9}$ \\
\hline Plant height(cm) & $290-340(310)$ & $310-350(322)$ & $250-280(270)$ & $270-305(285)$ \\
\hline $\begin{array}{c}\text { Basal } \\
\text { diameter(mm) }\end{array}$ & $19-23(20)$ & $19-25(22)$ & $15-18(16)$ & $15-18(17)$ \\
\hline $\begin{array}{c}\text { Plant } \\
\text { population } / \mathbf{m}^{\mathbf{2}}\end{array}$ & $44-50$ & $49-55$ & $47-50$ & $48-55$ \\
\hline
\end{tabular}

Figures in the parenthesis indicates average value

Table.5 Comparative man-days requirement per hectare under CT and ZT-Jute

\begin{tabular}{|c|c|c|c|c|}
\hline \multirow{2}{*}{ Components } & \multicolumn{2}{|c|}{$\mathbf{2 0 1 8}$} & \multicolumn{2}{|c|}{$\mathbf{2 0 1 9}$} \\
\cline { 2 - 5 } & ZT & CT & ZT & CT \\
\hline Seeding & 0 & 2 & 0 & 3 \\
\hline Fertilizer application & 2 & 3 & 2 & 60 \\
\hline $\begin{array}{c}\text { Weeding and } \\
\text { thinning }\end{array}$ & 6 & 55 & 6 & 32 \\
\hline $\begin{array}{c}\text { Harvesting } \\
\begin{array}{c}\text { Steeping, Retting and } \\
\text { Fibre extraction }\end{array}\end{array}$ & 35 & 30 & 40 & 25 \\
\hline Total & $\mathbf{7 3}$ & 25 & 35 & $\mathbf{1 2 2}$ \\
\hline
\end{tabular}

Table.6 Detailed cost of cultivation for ZT and CT-Jute

\begin{tabular}{|c|c|c|c|c|c|c|c|c|}
\hline \multirow[t]{2}{*}{ Year } & \multicolumn{4}{|c|}{ ZT-Jute } & \multicolumn{4}{|c|}{ CT-Jute } \\
\hline & $\begin{array}{c}\text { Total cost } \\
\text { of } \\
\text { cultivation } \\
\text { (Rs./ha) }\end{array}$ & $\begin{array}{c}\text { Gross } \\
\text { income* }^{*} \\
\text { (Rs./ha) }\end{array}$ & $\begin{array}{c}\text { Net } \\
\text { income } \\
\text { (Rs./ha) }\end{array}$ & $\begin{array}{l}B: C \\
\text { ratio }\end{array}$ & $\begin{array}{c}\text { Total cost } \\
\text { of } \\
\text { cultivation } \\
\text { (Rs./ha) }\end{array}$ & $\begin{array}{c}\text { Gross } \\
\text { income } \\
\text { (Rs./ha) }\end{array}$ & $\begin{array}{c}\text { Net } \\
\text { income } \\
\text { (Rs./ha) }\end{array}$ & $\begin{array}{l}\mathrm{B}: \mathbf{C} \\
\text { ratio }\end{array}$ \\
\hline 2018 & 29205 & 98150 & 68945 & 3.36 & 39215 & 78000 & 38785 & 1.99 \\
\hline 2019 & 31965 & 133875 & 101910 & 4.19 & 41065 & 104975 & 63910 & 2.56 \\
\hline
\end{tabular}

N.B.:(*)Market price for jute fibre was Rs. 3250 and Rs. 4250 per quintal in 2018 and 2019, respectively 
Table.7 Component-wise cost of cultivation for ZT and CT-Jute

\begin{tabular}{|c|c|c|c|c|}
\hline Components & \multicolumn{2}{|c|}{$\mathbf{2 0 1 8}$} & \multicolumn{2}{|c|}{$\mathbf{2 0 1 9}$} \\
\cline { 2 - 5 } & ZT & CT & ZT & CT \\
\hline $\begin{array}{c}\text { Land } \\
\text { preparation }\end{array}$ & 0 & 7500 & 0 & 7500 \\
\hline Seed & 480 & 600 & 450 & 565 \\
\hline Seeding & $3750\rfloor$ & 500 & 3750 & 500 \\
\hline $\begin{array}{c}\text { Fertilizer } \\
\text { application }\end{array}$ & 4450 & 3115 & 4740 & 3250 \\
\hline $\begin{array}{c}\text { Weeding and } \\
\text { thinning }\end{array}$ & 4275 & 13750 & 4275 & 15000 \\
\hline $\begin{array}{c}\text { Harvesting } \\
\text { Steeping, Retting } \\
\text { and Fibre } \\
\text { extraction }\end{array}$ & 8750 & 7500 & 10000 & 8000 \\
\hline Total & 7500 & 6250 & 8750 & 6250 \\
\hline & $\mathbf{2 9 2 0 5}$ & $\mathbf{3 9 2 1 5}$ & $\mathbf{3 1 9 6 5}$ & $\mathbf{4 1 0 6 5}$ \\
\hline
\end{tabular}

Table.8 Technology gap, extension gap and technology index recorded under ZT-Jute demonstration

\begin{tabular}{|c|c|c|c|}
\hline Year & $\begin{array}{c}\text { Technology } \\
\text { gap(kg/ha) }\end{array}$ & $\begin{array}{c}\text { Extension } \\
\text { gap(kg/ha) }\end{array}$ & $\begin{array}{c}\text { Technology } \\
\text { Index(\%) }\end{array}$ \\
\hline Pre-kharif 2018 & 780 & 620 & 20.52 \\
\hline Pre-kharif 2019 & 650 & 680 & 17.10 \\
\hline Mean & $\mathbf{7 1 5}$ & $\mathbf{6 5 0}$ & $\mathbf{1 8 . 8 1}$ \\
\hline
\end{tabular}

The overall saving or curtailment of cost in total cost of cultivation under ZT technology was attributed to the components 'land preparation' and 'weeding operations' (Table 7). No extra cost was incurred towards land preparation and at the same time the weeds were controlled through use of herbicides which was much cheaper than manual weeding. However, due to higher prices of complete complex fertilizers used in zero till drill, the cost involvement in fertilizer management was little bit higher under ZT technology. All together, around Rs. 9,00010,000 per hectare could be saved under ZT technology.

The technology gap, ranging from 780-650 $\mathrm{kg} / \mathrm{ha}$ with an average of $715 \mathrm{~kg} / \mathrm{ha}$, reflected the farmers' cooperation in carrying out the demonstrations with encouraging results (Table 8). The differences in technology gap may be attributed to variability in soil status and prevalent weather condition. With better execution of frontline demonstrations, it was possible to reduce the gap in subsequent years.

The extension gap increased slightly in the successive years (620 during 2018 and 680 during 2019).The increasing involvement of farmers towards adoption of this newly introduced technology is required to reverse the trend. Wider adoption of this particular technology may reduce the extension gap in future. 
Technology index was recorded to be decreased over the successive years of study. The technology index was varying from 20.52 $-17.10 \%$ with an average of $18.81 \%$ (Table 8). The successive decreased value of technology index reflected the feasibility of the technology. The lower the values of technology index more will be the feasibility of the demonstration (Jeengar et al., 2006; Mitra and Samajdar, 2013; Mitra et al., 2014). From the study it can be concluded that ZT technology can be considered as a successful technology in jute in terms of productivity as well as profitability. Appropriate policy decisions are required for its promotion in West Bengal and its adjoining areas

\section{References}

Annonymous.2018. Annual Report of AINP on Jute and Allied Fibres-2017-18, CRIJAF, Barrackpore

Bhattacharya, S.P., Mondal, L., Pal, D. And Saha, M. 2004. Bio-efficacy of Targa super (Quizalofop ethyl 5\% EC) for controlling weeds in jute. Pestology 28(4): 32-35.

Brown, P.R., Darbas, T., Kishore, A., RolaRubzen, F., Murray-Prior, R., Anwar, M., Hossain, S., Islam, R., Rashid, M., Nur-E-Alam, M., Siddquie, M., Datt, R., Kumar, U., Pradhan, K., Das, K.K., Dhar, T., Bhattacharya, P.M., Chowdhury, A.K., Ghosh, A., Sapkota, B., Thapa, D., Pokharel, D., Adhikari, S., Sugden, F., Saikia, P., de Silva, S., Maskey, N., Maharjan, S., Gathala, M. and Tiwari, T. 2017. Implications of Conservation Agriculture and Sustainable Intensification Technologies for Scaling and Policy: Synthesis of SRFSI Socio-economic Studies. CSIRO, IFPRI, Curtin University, IWMI, CIMMYT, partner organizations in EGP joint publication. ACIAR, Canberra, Australia.
Chauhan, B. S., Mahajan, G., Sardana, V., Timsina, J. and Jat, M. L. 2012. Productivity and sustainability of the rice-wheat cropping system in the indogangetic plains of the indian subcontinent: problems, opportunities, and strategies. Advances in Agronomy 117: 315-369.

Datta, M.K., Halder, P., Biswas, U. and Kundu, C.K.2017. Effect of different weed management practices on growth and yield of tossa jute (Corchorus olitorius) in the new alluvial zone of West Bengal, India. International Journal of Current Microbiology and Applied Sciences 6(11): 1118-1123.

Gathala, M. K., Kumar, V., Sharma, P. C., Saharawat, Y. S., Jat, H. S., Singh, M., et al., 2013. Optimizing intensive cereal-based systems addressing current and future drivers of agricultural change in the north western Indo-Gangetic plains of India. Agriculture, Ecosystems and Environment 177: 85-97.

Gathala, M.K., Timsina, J., Islam, M.S., Krupnik, T.J., Bose, T.R., Islam, N., Rahman, M.M., Hossain, M.I., HarunARRashid, Ghosh, A.K., Hasan, M.M.K., Khayer, M.A., Islam, M.Z., Tiwari, T.P. and McDonald, A.J. 2016. Productivity, profitability, and energetics: a multi- criteria and multilocation assessment of farmers' tillage and crop establishment options in intensively cultivated environments of South Asia. Field Crops Research 186: 32-46.

Ghorai, A.K., Chakraborty, A.K., Pandit, N.C., Monda, I.R.K. andBiswas, C.R. 2004. Grass weed control in jute by Targa super (quizalofop etthyl 5\% EC). Pestology, 28(2): 31-34.

Hobbs, P.R., Sayre, K. and Gupta, R. 2008. The role of conservation agriculture in sustainable agriculture. Philosophical Transactions of the Royal Society $B$ 
363: 543-555.

Islam, M. and Ali, S. 2017.Agronomic research advances in jute crops of Bangladesh. AASCIT Journal of Biology 3(6): 34-46.

Krishna, V., Keil, A., Aravindakshan, S. and Meena, M. 2016. Conservation Tillage for Sustainable Wheat Intensification: the Example of South Asia. Chapter 14.BurleighDodds Science Publishing Limited, pp. 1-21.

Kumari, K., Devegowda, SR and Kushwaha, S. 2018. Trend analysis of area, production and productivity of jute in India. The Pharma Innovation Journal 7 (12): 58-62.

Mahapatra, B.S., Mitra, S.,Sinha, M.K. and Ghorai AK. 2009. Research and development in jute and allied fibresin India: A review. Indian Journal of Agronomy 54(4): 361-373.

Mitra, B. and Samajdar, T. 2013. Frontline demonstration: an effective tool for enhancing the yield of jute in subHimalayan plains (Terai Zone) of West Bengal. Agricultural Science Digest, 33(1):38-41.

Mitra, B., Majumdar, K., Dutta, S.K., Mondal, T., Das, S., Banerjee, H., Ray, K. and Satyanarayana, T. 2019. Nutrient management in wheat (Triticum aestivum) production system under conventional and zero tillage in eastern sub-Himalayan plains of India. Indian Journal of Agricultural Sciences 89 (5): 775-784.

Mitra, B., Mookherjee, S. and Biswas, S. 2014. Promotion of short duration rice variety Gotra- Bidhan-1 (IET 17430) through frontline demonstration in Terai region of West Bengal. Journal of Crop and Weed 10(1): 111-114.

Mitra, B., Samajdar, T. and Islam, M. 2017. Effect of weed control measures in jute under Terai zone of West Bengal, India. Environment and Ecology 35(1): 84-87.

\section{How to cite this article:}

Biplab Mitra, Prateek Madhab Bhattacharya, Abhas Kumar Sinha, Rajat Chatterjee and Apurba Kumar Chowdhury. 2020. Zero Tillage Technology in Jute Cultivation: A Successful Venture in West Bengal. Int.J.Curr.Microbiol.App.Sci. 9(05): 2068-2075.

doi: https://doi.org/10.20546/ijcmas.2020.905.237 